\title{
News, Notes and Queries
}

\section{ACKNOWLEDGEMENTS}

My thanks are due to Dr. F. N. L. Poynter, Director, The Wellcome Historical Medical Museum and Library, London, for allowing me to study and illustrate the Yoruba figure; to Mr. W. B. Fagg, British Museum, London for helpful comments on it; and to Dr. K. E. Larsson, Etnografiska Museet. Goteborg, for allowing me to have photographs of the Babwende figure.

\section{REFERENCES}

1. Greenwald, IsidOR, 'The history of goiter in Africa', Bull. Hist. Med., 1949, 23, 155-85.

2. Leo, JoANnes, Africanus, Primo volume e seconde edition delle navigazione e viaggio ..., compiled by Giovanni Battista Ramusio, Venice, 1554.

3. Caravajal, luis de Marmol, Primera parte de la Descripcion general de Affrica, Granada, 1573.

3a. Park, Mungo, Travels in the Interior Districts of Africa, 1795-7, London, 1799, p. 276.

4. Bowditch, T. EDWARD, Mission from Cape Coast Castle to Ashantee, with a descriptive account of that Kingdom, London, 1819.

5. Daniell, William F., Sketches of the Medical Topography and Native Diseases of the Gulf of Guinea, Western Africa, London, 1849, pp. 114-15.

6. Cameron, Vernon L., Across Africa. Vol. 2, London, 1877, p. 522.

7. BeNTlEY, W. Holman, Dictionary and grammar of the Kongo language as spoken at San Salvador, the ancient capital of the Old Congo Empire, West Africa, London, 1887, p. 96.

8. WHITEHEAD, JOHN, Grammar and Dictionary of the Bobangi language as spoken over a part of the Upper Congo, West Central Africa, London, 1899.

9. Ghaloungui, Paul, Thyroid Enlargement in Africa with Reference to the Nile Basin, Cairo, The National Information and Documentation Centre, 1965.

10. Wellcome Historical Medical Museum. Catalogue of an Exhibition illustrating the Medicine of the Aboriginal Peoples of the British Commonwealth, London, Wellcome Historical Medical Museum, 1952, Section III, Pathology, p. 11 (5371/1936).

11. FAGG, W. B., personal communication.

12. BJÖRNBERG, A., 'Goitre in a Babwende carving', Etnografiska Museet, Góteborg Arstryck för 1957 och 1958, 1960, pp. 82-85.

13. Johnson, TH., The Workes of that famous Chirurgion Ambrose Parey Translated out of Latine and compared with the French, London, 1634, pp. 649-50.

CALVIN WELLS

\section{SIXTH BRITISH CONGRESS ON THE HISTORY OF MEDICINE University of Sussex, Brighton, 6-9 September 1967}

THE theme of this congress, which was organized by the British Society for the History of Medicine, was 'Medicine and Science in the 1860s'. The Congress President was Dr. Douglas Guthrie, and over one hundred residential members took part in the meeting, including a number of foreign delegates.

The first full day of the meeting was devoted to the following papers, given by specially invited speakers: (1) Clinical Medicine, by Dr. K. D. Keele. Dr. Keele said that the 1860 s constituted a decisive phase in the change from speculative medicine to medicine as an applied science. This is illustrated by the methods of examination 


\section{News, Notes and Queries}

and investigation of the period, and in the changing terminology of diagnoses, which still however remained markedly different from today. In treatment a nihilistic attitude began to break down before the discovery of anaesthetics, antiseptics, and a new appreciation of old drugs such as digitalis.

(2) Cellular Pathology, with Particular Reference to Virchow's Work and its Influence by Professor W. H. McMenemey. The speaker discussed the impact of the publication of Virchow's Cellular Pathology on contemporary medical thought, especially in the United Kingdom. The importance of Virchow's theory was assessed against a background of continuous histological and cytological research dating from the introduction of the compound achromatic microscope, research in which British scientists played an important part. The progress of pathology in the United Kingdom during the 1860s was compared with that in other countries.

(3) Animal Diseases and Public Health, by J. W. Barber-Lomax. This paper drew attention to the importance of the work of the Gamgee family, who campaigned increasingly for the control of animal disease and the prevention of the consequences of human consumption of diseased meat. Their efforts eventually resulted in legislation to protect both the animal and human population of the United Kingdom.

(4) The Impact of Darwin's 'Origin of Species' in Medicine and Biology, by Dr. Bernard Towers. The lecturer referred to contemporary records revealing the reception of Darwin's arguments by important scientists. There was great disagreement about major features of Darwinism, and its triumph was primarily philosophical, not scientific.

(5) The Dawn of the Germ Theory, by Mr. J. K. Crellin. This paper dealt with some of the relevant issues in the germ theory of disease which were raised in the 1860s, such as the choice of experimental techniques, the significance of a mechanistic or vitalistic outlook, and the impact of Darwin's theory of evolution.

(6) Antiseptic Surgery, by Dr. F. F. Cartwright. Early attempts to deal with the infected wound were described. The problem of infection in operative surgery following the introduction of anaesthesia in 1846 was assessed, together with Lister's principle and methods and their effect on surgical mortality. New facts were brought forward about the opposition to and the acceptance of antisepsis.

The papers on Friday, 8 September, were selected from those submitted by Congress members. They were as follows:

(7) Medical Chemistry and Chemical Medicine, by Dr. D. Noel Raine. The lecturer analyzed the development of clinical chemistry during this period, with particular emphasis on chemical methods of investigating disease.

(8) Medical Attendance on Royalty, by Dr. Neville M. Goodman. A study of the medical diaries of Dr. Edward Sieveking and his medical attendance on Edward, Prince of Wales (afterwards King Edward VII) and Princess Alexandra from 1863 to 1869 . The diaries were presented to the Royal College of Physicians in 1959.

(9) Research in Human Mycology, by Dr. Frances M. Keddie. This paper discussed the beginnings of medical mycology in the early nineteenth century; opinions on the parasitical nature of fungi: and the early discovery of the fungus in tinea versicolor. The clinical aspects of tinea versicolor were described in the 1860s, and then largely forgotten until the 1930s. 


\section{News, Notes and Queries}

(10) The Dental Profession, by Mr. N. David Richards. The development of professional interests up to 1860 were briefly described, the major event being the introduction of the L.D.S. of the Royal College of Surgeons. The speaker went on to describe the amalgamation of the two professional bodies, the College of Dentists and the Odontological Society of London, to form the Odontological Society of Great Britain, and the development of dental hospitals and schools which facilitated the introduction of formal training of dentists.

(11) Occupational Health, by Dr. W. R. Lee. Advances in legislation governing employment in mines, factories, and agriculture, were discussed. Much of this progress was helped by the evidence of and pressure from doctors and trades unions. It is interesting to note that the 1860 s also saw the formation of a group of doctors to encourage and protect their own interests in industry.

(12) Lister and the Development of Abdominal Surgery, by Mr. John Shepherd. The last quarter of the nineteenth century saw a rapid and spectacular advance in abdominal surgery. Lister's own work in this field was surveyed and an assessment made of his influence.

(13) Notes on West African Public Health, by Dr. R. Schram. In West Africa the 1860s were of crucial importance. While hospitals did not commence on any scale until the twentieth century, the beginnings of curative and public health services were all present and active. Their origins were recorded, together with the efforts of a few pioneer African doctors who were active on the Coast in Sierra Leone, Ghana, and Nigeria in that decade.

(14) Medical Literature, by Mr. E. Gaskell. Mr. Gaskell described the periodical literature of the decade, and books also, and traced trends, strengths and weaknesses. He pointed out that not only were journals increasing in number, but they were beginning to specialize and to concentrate more on reporting the latest advances in medical research.

The final session of the Congress was devoted to 'The Sociology of Medicine and the Rise of Statistics', and the papers were as follows:

(15) The Development and Use of Statistics in Social Medicine, by Dr. Ruth G. Hodgkinson. This study was divided into three parts: (i) why there was need at this time for accurate information; (ii) what was available; (3) what had to be done. The types of investigation for collecting facts and figures for the promotion of State Medicine and the Public Health Services were compared, namely, the inquiries undertaken by individuals or societies on the one hand and those by the State on the other. Achieving accuracy and comprehensiveness was the problem, but quantity information and its dissemination was the primary necessity for reform during the period.

(16) The Anatomy of State Medicine: Concept and Application, by Mr. Roy M. MacLeod. The developing relationship between the medical profession and the formulation of public policy has recently excited considerable interest among medical historians and medical sociologists. Little has yet been said, however, about the manner in which 'State Medicine', as a concept, was influenced by the professional and institutional circumstances of mid-Victorian Britain. This paper endeavours to clarify this influence, by analyzing 'State Medicine' in the wider context of the 


\section{News, Notes and Queries}

'Nineteenth-century Revolution in Government.'

(17) The Causes of Death and Morbidity in the Royal Navy, by Surgeon Captain F. P. Ellis. By the 1860 s the Annual Reports on the Health of the Navy were well established. This paper discussed the main causes of death, and morbidity as revealed by an analysis of these Reports, and compared them with the causes in the civilian population.

All the papers given at the Congress are to be published in full in due course, edited by the Honorary Secretary of the Congress, Dr. F. N. L. Poynter.

\section{Faculty of the History of Medicine and Pharmacy Maccabaean Prize and Medal}

Entries for the 1968 Maccabaean Prize of 25 guineas and a bronze medal are now invited for an essay of 5,000 to 7,000 words on some aspect of the history of medicine or pharmacy. Intending candidates, who must be under thirty years of age on 15 March, 1968, may apply for further particulars to the Hon. Secretary of the Faculty (Dr. F. N. L. Poynter, The Wellcome Historical Medical Library, The Wellcome Building, Euston Road, London, N.W.1.)

\section{UNIVERSITY OF PARIS \\ Department of THe History of Medicine AND SURGery}

A course of lectures on 'The Middle Ages' commenced on 16 November, 1967, organized by the head of the department, Professor Charles Coury. A wide variety of subjects is to be covered in this course, which will continue until 4 April 1968. They include: Byzantine medicine (the clinical and biological sciences); Islamic medicine; the Schools of Salerno and Montpellier; hospitals; the medieval universities of Paris, Bologna, and Padua; epidemics; pharmacology and therapeutics.

\section{American Association for the History of Medicine}

The Washington University School of Medicine and the Department of History are to be co-hosts to the American Association for the History of Medicine at its meeting in St. Louis on 18-20 April, 1968.

Sessions will be devoted to the history of pharmacy (arranged by the American Institute for the History of Pharmacy), medieval and renaissance medicine in the Vatican Archives (at Pius XII Library), local St. Louis area medical history, and other topics. The banquet speaker is the Editor of the papers of Lewis and Clark. 